\title{
STUDI KOMPARASI PEMBELAJARAN TEMATIK MENGGUNAKAN MODEL INKUIRI DAN INTERAKTIF UNTUK PENGEMBANGAN SIKAP PEDULI LINGKUNGAN DAN PELESTARIAN BIODIVERSITY BAGI SISWA KELAS IV SDN 11 KOTA BENGKULU
}

\author{
Victoria Karjiyati \\ Universitas Bengkulu
}

\begin{abstract}
Abstrak
Penelitian ini bertujuan untuk membandingkan sikap peduli lingkungan antara siswa yang mengikuti pembelajaran tematik menggunakan model inkuiri dan interaktif pada siswa kelas IV SDN 11 Kota Bengkulu. Jenis penelitian ini adalah penelitian eksperimen semu. Sampel penelitian ini adalah siswa kelas IV A yang berjumlah 35 siswa sebagai kelas eksperimen I menggunakan model inkuiri dan kelas IV B yang berjumlah 34 siswa sebagai kelas eksperimen II menggunakan model interaktif. Instrumen penelitian ini menggunakan lembar observasi dan dokumentasi. Tehnik analisis data menggunakan Uji-t dua sample independen. Hasil analisis data menunjukkan bahwa $t_{\text {hitung }}$ sebesar $-0,06$ lebih kecil dari pada $\mathrm{t}_{\text {tabel }}$ sebesar 1,67 pada taraf signifikan 0,05. Hasil analisis uji hipotesis menggunakan Uji-t dua sample independen diperoleh bahwa tidak terdapat perbedaan hasil belajar aspek sikap anatara siswa yang mengikuti pembelajaran menggunakan inkuiri dengan siswa yang menggunakan model pembelajaran interaktif. Kesimpulan dalam penelitian ini tidak terdapat perbedaan hasil belajar sikap peduli lingkungan dan pelestarian biodiversity antara siswa yang mengikuti pembelajaran tematik menggunakan model inkuiri dengan siswa yang mengikuti pembelajaran menggunakan model interaktif.
\end{abstract}

Kata Kunci : $\quad$ Pembelajaran Tematik, Model Inkuiri, Model Interaktif, Sikap Peduli Lingkungan, Pelestarian Biodiversity

\section{PENDAHULUAN}

Perubahan lingkungan yang ditandai dengan berbagai macam polusi, panas global, ancaman kepunahan keanekaragaman hayati, dan lenyapnya hutan di Indonesia sudah sangat serius. Upaya penanganan melalui berbagai aspek sudah dilakukan, namun kenyataannya kondisi alam masih sangat memprihatinkan. Upaya Pendidikan Lingkungan Hidup (PLH) diharapkan berdampak nyata bagi pengembangan sikap yang ramah/peduli lingkungan dan pelestarian biodiversity.

Konsep PLH diangkat berdasarkan isuisu lingkungan hidup dan biodiversity. Isuisu lingkungan dan biodiversity secara garis besar mencakup : pengurangan keanekaragaman, besarnya jumlah penduduk, dan polusi. Isu-isu lingkungan bersifat multidisipliner dan dapat dimasukkan ke dalam beberapa topik pembelajaran sains, dengan berbagai alternatif lebih kontemporer dan materi yang relevan untuk siswa dan guru. Guru SD dapat menyajikan pendidikan 
lingkungan pada waktu tertentu dan sesuai dengan isi materi pelajaran.

Beberapa contoh isu-isu lingkungan yang dapat dimasukkan ke dalam pembelajaran tematik, antara lain yaitu: masalah penggundulan hutan, hilangnya habitat, polusi udara, polusi air, polusi kimiawi (seperti DDT, terjadinya hujan asam dan berbagai limbah beracun), kebakaran hutan dan panas global, efek rumah kaca, hilangnya keanekaragaman hayati, eksplorasi minyak dan gas bumi, menipisnya sumber energi fosil, radiasi nuklir, kepadatan penduduk, kekurangan gizi, kehidupan berpindah, kesehatan (gangguan pernafasan kronis karena kontaminasi/polusi udara), racun organik, kebocoran radioaktif, kebisingan dan pemborosan (Dalifa dan Winarni, 2010: 12).

Perubahan alam secara global Walker, B \& Steffen, W. (1997), menyatakan bahwa ada 4 (empat) penggerak utama perubahan global dari alam, yaitu: (1) Berubahnya komposisi atmosfer, dalam hal ini dikarenakan peningkatan $\mathrm{CO} 2$, gas-gas rumah kaca, dan peningkatan CFC, (2) Penggunaan lahan yang berubah, dalam hal ini mencakup konversi dari satu jenis lahan berubah menjadi yang lain, dan perubahanperubahan dalam pemupukan, pengolahan tanah serta perubahan dalam ketersediaan air permukaan dan aliran sungai, (3) berkurangnya keanekaragaman hayati pada sebagian besar kawasan dunia, dan (4) Perubahan iklim seperti: cuaca buruk, seperti musim kering yang berkepanjangan dan banjir pada musim hujan yang secara luas menyebabkan kerusakan di lingkungan dan mengganggu kesejahteraan hidup masyarakat.

Contoh isu lingkungan lainnya adalah ancaman punahnya sumber daya alam hayati khususnya di Indonesia. Indonesia merupakan negara yang sangat kaya akan spesies, walaupun luasnya hanya $1,3 \%$ dari luas daratan dunia. Indonesia memiliki sekitar 17\% jumlah spesies di dunia, minimal diperkirakan memiliki $11 \%$ spesies tumbuhan berbunga yang sudah diketahui, $12 \%$ hewan menyusu, $15 \%$ amfibi dan reptil, $17 \%$ jenis burung, dan paling tidak $37 \%$ jenis ikan yang ada di dunia (KLH, 1994). Ada data tentang habitat alami yang sangat luas (mencapai 44\%) yang telah dikonversi. Jadi tidak mengherankan jika Indonesia memiliki daftar terpanjang di dunia mengenai jumlah spesies yang terancam punah, yaitu 126 jenis burung, 63 jenis mammalia, 21 jenis hewan reptil, dan 65 spesies hewan Indonesia lainnya kini terancam punah, karena implikasinya lebih dari satu spesies dalam sehari hilang dalam setiap tahunnya.

Indonesia secara keseluruhan memiliki hutan hingga $91 \%$ di berbagai kawasan berdasarkan penghitungan awal tahun 1980-an. Pada saat itu, kebanyakan propinsi telah kehilangan sekitar $80 \%$ atau lebih kawasan hutan dataran rendahnya, dan 11 propinsi telah mengalami penggundulan lahan curam yang cukup besar. Kecepatan lenyapnya hutan tidak diketahui dengan tepat, diperkirakan sekitar 700.000 sampai 1,2 juta hektar tiap tahun. Lenyapnya hutan ini terutama disebabkan oleh kegiatan penebangan atau pembukaan hutan untuk pertanian dan perkebunan.

Berdasarkan uraian di atas, menggambarkan bahwa kerusakan alam di Indonesia sudah sangat serius. Berbagai upaya penanganan melalui berbagai aspek sudah dilakukan, namun kenyataannya belum membuahkan hasil seperti yang diharapkan. Untuk itu upaya penanggulangan melalui jalur PLH sejak dini sangat penting dilakukan dan harus menjadi perhatian yang serius, sehingga setidaknya untuk masa yang 
akan datang masih dapat menjaga sumber daya alam yang masih tersisa ini.

Isu-isu lingkungan dan biodiversity lokal yang sehari-hari dihadapi oleh masyarakat harus dikemas dalam pembelajaran, salah satunya melalui pembelajaran tematik berbasis inkuiri menggunakan pendekatan saintifik kurikulum 2013 di SD.

Penerapan kurikulum 2013, sistem pembelajarannya menggunakan pendekatan tematik integratif. Pembelajaran tematik integratif merupakan pendekatan pembelajaran yang mengintegrasikan berbagai kompetensi dari berbagai mata pelajaran ke dalam berbagai tema (Kemendikbud, 2013: 27-33). Salah satu kompetensi yang akan dicapai di SD adalah penanaman kesadaran dan kepedulian terhadap lingkungan hidup. Kompetensi tersebut dikembangkan secara otentik, dengan harapan siswa memiliki sikap peduli lingkungan dan pelestarian biodiversity. Menyadari pentingnya PLH dalam membantu mengatasi isu-isu lingkungan hidup, maka kebijakan PLH diarahkan pada tumbuhnya kepedulian terhadap isu-isu lingkungan hidup dan biodiversity. Salah satu alternatif PLH di SD melalui pembelajaran tematik menggunakan model inkuiri menggunakan pendekatan saintifik.

Inkuiri adalah suatu proses untuk mengembangkan kemampuan-kemampuan ilmiah yang mendasar yang meliputi mengobservasi, mengklasifikasi, menghitung, merumuskan hipotesis, membuat relasi ruang dan waktu, mengukur, menginterpretasikan data, merancang eksperimen, memperoleh data, menganalisis dan menginterpretasi data, membuat prediksi, dan mengkomunikasikan data.

Winarni (2012: 24), menyatakan bahwa model pembelajaran inkuiri adalah salah satu model pembelajaran yang mengutamakan proses penemuan dalam kegiatan pembelajaran untuk memperoleh pengetahuan. Secara umum model pembelajaran inkuiri terbagi atas lima tahap, yaitu (1) penyajian masalah (confrontation with problem); (2) pengumpulan data verifikasi (data gathering-verification); (3) pengumpulan data eksperimentasi (data gathering-experimentation); (4) organisasi data dan formulasi kesimpulan (organizing, formulating, and explanation); dan (5) analisis proses inkuiri (analysis of the inquiry process).

Pada pembelajaran tematik selain menggunakan model inkuiri juga dapat diterapakan model yang lain salah satunya model interaktif. Model interaktif dikenal juga dengan pendekatan "pertanyaan siswa". Dalam pembelajaran guru berusaha untuk menggali pertanyaan siswa sehingga siswa ditantang rasa ingin tahunya terhadap suatu objek yang sedang dipelajari dengan cara mengajukan pertanyaan kemudian melakukan penyelidikan atas pertanyaan mereka sendiri (Faire dan Cosgrove dalam Winarni, 2012: 15). Kedua model tersebut sama-sama memiliki keunggulan dalam mengembangkan higher order thingking (HOT).

Menurut Faire dan Cosgrove dalam Winarni (2012: 16), langkah-langkah model interaktif terbagi menjadi tujuh tahap yaitu: (1) persiapan; (2) pengetahuan awal; (3) eksplorasi; (4) siswa merumuskan pertanyaan; (5) penyelidikan; pengetahuan akhir; dan (7) refleksi. Secara operasional dari setiap tahap pembelajaran interaktif adalah sebagai berikut: (1) persiapan, dalam tahap ini guru dan siswa memilih topik yang akan dikaji. (2) pengetahuan awal, dalam tahap ini guru mengajukan sejumlah pertanyaan untuk menggali hal-hal yang sudah diketahui maupun belum diketahui siswa mengenai 
topik yang dikaji. (3) eksplorasi, dalam tahap ini rasa ingin tahu siswa dirangsang sehingga mengajukan pertanyaan berkaitan dengan topik kegiatan. (4) siswa merumuskan pertanyaan, dalam tahap ini pertanyaanpertanyaan siswa diseleksi/dirumuskan kembali sehingga muncul beberapa pertanyaan saja yang akan dicari jawabannya. (5) penyelidikan, dalam tahap ini siswa dibantu guru dalam melakukan diskusi, penelitian/percobaan, dan pencarian informasi untuk menemukan jawaban atas pertanyaan yang muncul. (6) pengetahuan akhir, dalam tahap ini siswa mengungkapkan hal-hal yang telah diketahui berkaitan dengan topik yang dibahas serta membandingkan apa yang kini siswa ketahui dan apa yang sebelumnya siswa ketahui. (7) refleksi, dalam tahap ini siswa melakukan refleksi tentang apa yang telah dilakukan, apa yang dulu diketahui, apa yang siswa ketahui sekarang, serta apa yang belum dan ingin siswa ketahui.

Berdasarkan kedua model pembelajaran yang dipaparkan di atas, peneliti menguji perbedaan hasil belajar aspek sikap kedua model tersebut dalam pembelajaran pada siswa kelas IV SDN 11 Kota Bengkulu.

\section{METODE}

Jenis penelitian ini adalah penelitian eksperimen semu. Penelitian eksperimen semu merupakan desain penelitian eksperimen dengan pengontrolan yang sesuai dengan kondisi yang ada (situasional) (Sudjana, 1992:44). Penelitian ekperimen bertujuan untuk menguji hipotesis yang diajukan, memprediksi kejadian dalam ekperimental, serta menarik generalisasi hubungan antar variabel. Pada penelitian ini menguji dua model pembelajaran menggunakan dua kelas eksperimen.
Penelitian ini dilaksanakan di SD Negeri 11 Jalan Kolonel Barlian kota Bengkulu. Sample dalam penelitian ini adalah siswa kelas IVA berjumlah 35 sebagai kelas eksperimen I menggunakan model inkuiri dan siswa kelas IVB sebagai kelas eksperimen II mengunakan model interaktif.

Tehnik pengumpulan data menggunakan observasi dan dokumentasi. Observasi digunakan untuk mengamati sikap peduli lingkungan dan pelestarian biodiversity yang terdiri dari sikap tanggung jawab, disiplin, kreatif dan peduli lingkungan.

Tehnik analisis data dalam penelitian ini menggunaka Uji-t dengan pooled varian untuk 2 sample independen, dengan rumus :

$$
\mathrm{t}=\frac{\overline{\mathrm{x}_{1}}-\overline{\mathrm{x}_{2}}}{\sqrt{\frac{\left(\mathrm{n}_{1}-1\right) \mathrm{s}_{1}^{2}+\left(\mathrm{n}_{2}-1\right) \mathrm{s}_{2}^{2}}{\mathrm{n}_{1}+\mathrm{n}_{2}-2}\left(\frac{1}{\mathrm{n}_{1}}+\frac{1}{\mathrm{n}_{2}}\right)}}
$$

(Sugiyono, 2011:209)

Jika nilai $t_{\text {hitung }}$ lebih besar dari pada $t_{\text {tabel }}$ pada taraf signifikan 0,05 dan derajat kebebasan $(\mathrm{dk})=\mathrm{n}_{1}+\mathrm{n}_{2}-2$, maka terdapat perbedaan yang signifikan.

\section{HASIL}

Data sikap peduli lingkungan dan pelestarian biodiversity dianalisis menggunakan uji normalitas yang bertujuan untuk mengetahui apakah kedua kelas sampel pada penelitian ini berdistribusi normal atau tidak normal. Uji normalitas dilakukan menggunakan tes chi kuadrat. Suatu dikatakan berdsitribusi normal jika hsil perhitungan diperoleh nilai $\chi^{2}{ }_{\text {hitung }}<\chi^{2}{ }_{\text {tabel. Hasil }}$ perhitungan uji normalitas pada kelas eksperimen I dan eksperimen II disajikan pada tabel berikut : 
Tabel 1

Hasil Analisis Uji Normalitas

\begin{tabular}{lccc}
\hline \multicolumn{1}{c}{ Kelas } & $\chi_{\text {hitung }}^{2}$ & $\chi_{\text {tabel }}^{2}$ & Keterangan \\
\hline Eksperimen & 5,91 & & \\
I (IVA) & & 11,10 & $\mathrm{H}_{0}$ diterima \\
Eksperimen & 8,09 & & \\
II (IVB) & & & \\
\hline
\end{tabular}

Berdasarkan tabel di atas menunjukkan bahwa nilai $\chi_{\text {hitung }}^{2}$ eksperimen I sebesar 5,91 dan nilai $\chi_{\text {hitung }}^{2}$ eksperimen II sebesar 8,09 lebih kecil dari nilai $\chi^{2}$ tabel sebesar 11,10 pada taraf signifikan 0,05. Artinya kelas eksperimen I dan eksperimen II berdistribusi normal.

Setelah dilakukan uji normalitas kedua sampel, digunakan juga uji homogenitas yang bertujuan untuk mengetahui apakah kedua kelas sampel tersebut homogen atau tidak, uji homogenitas menggunakan uji F. Sampel dikatakan homogen apabila $F_{\text {hitung }}$ lebih kelcil dari pada $F_{\text {tabel }}$ pada taraf signnifikan 0,05. Hasil perhitungan uji $F$ pada kelas eksperimen I dan eksperimen II disajikan pada tabel berikut :

Tabel 2

Hasil Analisis Uji F

\begin{tabular}{lcc}
\hline \multirow{2}{*}{ Data } & \multicolumn{2}{c}{ Kelas } \\
\cline { 2 - 3 } & $\begin{array}{c}\text { Eksperimen } \\
\text { I (IVA) }\end{array}$ & $\begin{array}{c}\text { Ekeperimen } \\
\text { II (IVB) }\end{array}$ \\
\hline Rata-rata & 67,00 & 68,00 \\
Varian & 467,73 & 427,31 \\
$\mathrm{~N}$ & 35 & 34 \\
$\mathrm{DF}$ & 34 & 33 \\
F $_{\text {hitung }}$ & \multicolumn{2}{c}{1,09} \\
F $_{\text {tabel }}$ & \multicolumn{2}{c}{1,78} \\
\hline Kesimpulan & \multicolumn{3}{c}{$\mathrm{H}_{0}$ diterima } \\
\hline
\end{tabular}

Berdasarkan tabel di atas menunjukkan bahwa nilai $F_{\text {hitung }}$ sebesar 1,09 lebih kecil dari $F_{\text {tabel }}$ sebesar 1,78 pada taraf signifikan 0,05 . Artinya status varian kelas eksperimen
I dan eksperimen II berasal dari varian yang homogen.

Pengujian hipotesis penelitian dilakukan dengan menggunakan Uji-t. Apabila $t_{\text {hitung }}<t_{\text {tabel }}$ berarti tidak terdapat perbedaan yang signifikan antara kelas eksperimen I dan kelas eksperimen II dan sebaliknya, jika $t_{\text {hitung }}>t_{\text {tabel }}$ berarti terdapat perbedaan yang signifikan anatara kelas eksperimen I dan kelas eksperimen II. Hasil pengujian hipotesis tehadap kedua kelas sample untuk data hasil belajar aspek sikap peduli lingkungan dan pelestarian biodiversity disajikan pada tabel berikut :

Tabel 3

Hasil Analisis Uji-t

\begin{tabular}{lcc}
\hline \multirow{2}{*}{ Data } & \multicolumn{2}{c}{ Kelas } \\
\cline { 2 - 3 } & $\begin{array}{lcc}\text { Eksperimen } \\
\text { I (IVA) }\end{array}$ & $\begin{array}{c}\text { Eksperimen } \\
\text { II (IV B) }\end{array}$ \\
\hline Rata-rata & 66,67 & 67,89 \\
Varian & 441,18 & 438,27 \\
$\mathrm{~N}$ & 34 & 35 \\
$\mathrm{DF}$ & \multicolumn{2}{c}{67} \\
$\mathrm{t}_{\text {hitung }}$ & \multicolumn{2}{c}{$-0,06$} \\
$\mathrm{~T}_{\text {tabel }}$ & \multicolumn{2}{c}{1,67} \\
\hline Kesimpulan & \multicolumn{2}{c}{$\mathrm{H}_{0}$ diterima } \\
\hline \multicolumn{2}{c}{} \\
\hline
\end{tabular}

Berdasarkan tabel di atas menunjukkan bahwa nilai $t_{\text {hitung }}$ sebesar -0,06 lebih kecil dari $t_{\text {tabel }}$ sebesar 1,67 pada taraf signifikan 0,05 . Artinya tidak terdapat perbedaan sikap siswa yang signifikan antara siswa kelas eksperimen I yang menggunakan model inkuiri dengan kelas eksperimen II yang menggunakan model interaktif.

\section{PEMBAHASAN}

Berdasarkan hasil penelitian tidak terdapat perbedaan yang siginifikan sikap peduli lingkungan dan pelestarian biodiversity siswa kelas eksperimen I yang menggunakan model inkuiri dengan kelas eksperimen II yang menggunakan model 
interaktif. Nilai sikap yang dikembangkan dalam penelitian ini adalah sikap tanggung jawab, disiplin, kreatif dan peduli lingkungan. Objek penanaman sikap peduli lingkungan dan pelestarian biodiversity dalam peneltian ini terdiri dari lima komponen, yaitu : 1) membuang sampah pada tempatnya, 2) memanfaatkan sampah untuk pembuatan pupuk kompos, 3) merawat hewan peliharaan, 4) merawat tumbuhan dan 5) memanfaatkan sampah non-organik untuk produk kreatif/ karya seni. Sikap peduli lingkungan dan pelestarian biodiversity yang dimiliki siswa kelas IV SDN 11 Kota Bengkulu berada pada kategori baik. Siswa telah memiliki pengetahuan dan sikap kepedulian terhadap lingkungan. Sesuai pendapat Nay dalam Winarni (2012:156) sikap secara umum memiliki tiga komponen yaitu : 1) kognitif, adalah keyakinan terhadap objek sikap, 2) afektif, adalah perasaan terhadap objek sikap dan 3) kognitif, adalah kecendrungan untuk bertindak dengan cara nyata untuk respect terhadap objek sikap.

Sikap peduli lingkungan dan pelestarian biodiversity siswa kelas IV SDN 11 Kota Bengkulu yang menggunakan model inkuiri dengan model interaktif tidak terdapat perbedaan. Hal ini disebabkan kedua model tersebut sama-sama menekankan kepada siswa untuk memiliki sikap tanggung jawab, disiplin, kreatif dan peduli lingkungan. Sikap peduli lingkungan ini ditunjukkan perilaku siswa sehari-hari dalam hal : membuang sampah pada tempatnya, memanfaatkan sampah untuk pembuatan pupuk kompos, merawat hewan peliharaan, merawat tumbuhan dan memanfaatkan sampah nonorganik untuk produk kreatif/ karya seni. Dengan sikap tanggung jawab, disiplin, kreatif dan peduli lingkungan yang dimiliki siswa maka siswa dapat berfikir kritis, logis dan sistematis dalam menemukan pemecahan masalah dalam pembelajaran. Selain itu dalam bekerja kelompok siswa dituntut untuk menghargai orang lain agar tercipta komunikasi yang baik. Hal ini sejalan dengan pendapat Amri dan Ahmadi (2010:104) mengemukakan bahwa model inkuiri membimbing melatih dan membiasakan siswa berfikir kritis dalm proses pembelajaran. Selanjutnya menurut Poedjiadi (2007:81) pembelajaran menggunakan model interaktif memacu siswa berfikit kritis baik dalam mencari masalah maupun memecahkan masalah.

\section{SIMPULAN}

Berdasarkan hasil penelitian disimpulkan bahwa tidak terdapat perbedaan sikap peduli lingkungan dan pelestarian biodiversity antara siswa yang mengikuti pembelajaran tematik menggunakan model inkuiri dan interaktif pada siswa kelas IV SDN 11 Kota Bengkulu.

\section{DAFTAR PUSTAKA}

Amri, S. Dkk. 2010. Proses Pembelajaran

Kreatif dan Inovatif dalam kelas. Jakarta: PT Prestasi Pustakarya

Kemendikbud. 2013. Bahan Pelatihan Kurikulum 2013. Jakarta: Pusbangprodik.

Poejijadi, Anna. 2007. Sains Teknologi masyarakat (model pembelajaran kontekstual bermuatan nilai). Bandung: PT remaja Rosda Karya

Sudjana, Nana. Dkk. 1992. Penelitian dan Penilaian Pendidikan. Bandung: Sinar Baru 
Victoria Karjiyati

Sugiyono. 2011. Metode Penelitian

Kuantitatif Kualitatif dan $R \quad \& \quad D$.

Bandung: Alfabeta

Walker, B and Steffen, W. 1997. An Overview of the Implications of Global Change for Natural and Managed Terrestrial Ecosystems. Conservation Ecology [online]1(2):2. Avalaible from the Internet.

Winarni, Endang, W. 2011. Penelitian Pendidkan. Bengkulu: FKIP Unib

Winarni, Endang, W. 2012. Inovasi Dalam Pembelajaran IPA. Bengkulu: Unit Penerbitan FKIP UNIB 